\title{
FACTORS AFFECTING THE ABUNDANCE OF RUDERAL SPECIES AND Megathyrsus maximus, AN INVASIVE C4 GRASS IN ATLANTIC FOREST RESTORATION SITES
}

\author{
Jézili Dias $^{1 *}$, José Marcelo Domingues Torezan ${ }^{2}$ \\ ${ }^{1 *}$ Universidade Tecnológica Federal do Paraná, Câmpus Ponta Grossa. Departamento Acadêmico de Ensino. Laboratório de Botânica e \\ Conservação da Natureza (LBCN - UTFPR). Brasil - diasj@utfpr.edu.br* \\ ${ }^{2}$ Universidade Estadual de Londrina, Paraná, Brasil. Departamento de Biologia Animal e Vegetal. Laboratório de Restauração de \\ Ecossistemas (LABRE-UEL). Programa de Pós-Graduação em Ciências Biológicas: Biodiversidade e Conservação em Habitats \\ Fragmentados - torezan@uel.br
}

Received for publication: 31/05/2019 - Accepted for publication: 27/04/2020

\begin{abstract}
Resumo
Fatores afetam a abundância de espécies ruderais de Megathyrsus maximus, uma gramínea C4 invasora em áreas de Restauração da Floresta Atlântica. A gramínea exótica invasora Megathyrsus maximus (Capim Guiné) tem sido reportada como um filtro para a regeneração de espécies lenhosas nos primeiros anos da restauração de florestas tropicais. Objetivou-se avaliar sítios de restauração florestal, correlacionando a densidade e biomassa de M. maximus e de outras espécies ruderais com a idade das áreas, abertura de dossel, riqueza e abundância de árvores plantadas e a fertilidade do solo. Foram selecionados dezessete sítios de restauração, com plantios entre 40 e 110 meses, no Reservatório de Capivara no Sul do Brasil. Em cada área, dez parcelas de $10 \mathrm{~m}^{2}$ cada, com quatro subparcelas de $1 \mathrm{~m}^{2}$ foram alocadas, onde foi verificada a fertilidade do solo, abundância (M. maximus, plantas nativas e ruderais) e a biomassa seca (M. maximus e ruderais). Todas as áreas apresentaram alta fertilidade do solo, e a abertura do dossel $(21.5 \%$ a $38.5 \%)$ decresceu com o tempo. A abundância de espécies ruderais esteve relacionada com a abertura do dossel e a idade do plantio. A biomassa seca (que variou de 0 a $182 \mathrm{~g} / \mathrm{m}^{2}$ ) e densidade de $M$. maximus (que variou de 0 a 2 moitas por $\mathrm{m}^{2}$ ) não estiveram relacionadas com a idade ou abertura do dossel. Ainda, com exceção da concentração de magnésio no solo, nenhuma das variáveis relacionadas à fertilidade do solo, explicaram a abundância de $M$. maximus, indicando alta plasticidade fenotípica. É importante destacar que quase 10 anos após o plantio, os locais reflorestados não suprimiram com sucesso o Megathyrsus maximus, embora a abertura do dossel tenha diminuído.
\end{abstract}

Palavras-chave: abertura de dossel, biomassa seca, fertilidade do solo, gramínea exótica, reflorestamento.

\begin{abstract}
The non-native grass Megathyrsus maximus (Guinea grass) have been reported as a threat for woody species regeneration in the first years of tropical forest restoration, in some cases persisting for several years. The objective of this work was to evaluate forest restoration sites, correlating M. maximus and other ruderal species density and dry biomass with reforestation age, canopy openness, species richness, abundance of planted trees, and soil fertility. Seventeen sites reforested with native species were selected, with planting ages between 40 and 110 months, at the Capivara Reservoir, Southern Brazil. In each site, ten 10- $\mathrm{m}^{2}$ plots each with four $1-\mathrm{m}^{2}$ subplots were installed, where soil fertility, plant abundance (M. maximus, native and ruderal species) and dry biomass ( $M$. maximus and ruderal species only) were recorded. All sites showed high fertility soils, and the canopy openness $(21.5$ a $38.5 \%)$ decreased with time. Ruderal species abundance were positively correlated with canopy openness and negatively correlated with planting age. Both dry biomass (ranging from 0 to $182 \mathrm{~g} / \mathrm{m}^{2}$ ) and clump density (ranging from 0 to 2 clumps per $\mathrm{m}^{2}$ ) of $M$. maximus were not correlated with reforestation age or canopy cover. Moreover, with the exception of soil magnesium concentration, none of soil fertility variables could explain M. maximus abundance or biomass, indicating a high phenotypic plasticity in this non-native grass species. It was remarkable that almost 10 years after planting, the reforested sites did not successfully suppress Megathyrsus maximus even though canopy openness decreased.
\end{abstract}

Keywords: canopy openness, dry biomass, non-native grass, reforestation, soil fertility.

\section{INTRODUCTION}

Reforestation with native species has been considered the most appropriate forest restoration action in highly degraded sites because it can accelerate the re-creation of conditions needed to enhance the establishment of native species. Reforestation development should lead to an increasing canopy cover, which can displace shade-intolerant non-native species and ameliorate soil and microclimatic conditions for native species, giving rise to natural regeneration (SOUZA \& BATISTA 2004). However, some non-native species can persist in reforestation sites (MANTOANI et al. 2012), and thus compete with native species.

FLORESTA, Curitiba, PR, v. 50, n. 4, p. 1931 - 1938, out/dez 2020.

Dias, J. et.al.

ISSN eletrônico 1982-4688

DOI: $10.5380 /$ rf.v50 i4. 67192 
One notorious case in tropical forest restoration is Guinea grass (Megathyrsus maximum (Jacq.) B. K. Simon \& S. W. L. Jacobs), a non-native C4 grass that remains in the understory of many sites for several years after planting and has been reported for negative effects on natural regeneration (AMMONDT \& LITTON 2012; MANTOANI et al. 2012; AMMONDT et al. 2013; MANTOANI \& TOREZAN 2016). Guinea grass is an African species that was introduced in Brazil centuries ago for feeding cattle and has since expanded throughout the country, occupying degraded lowland sites, it was recently listed as an exotic invasive species in Brazil (DIAS et al. 2013; SAMPAIO \& SCHMIDT, 2013). The species shows an intense seed set during almost all year, has a long-lasting soil seed bank, and can regrow after fire (FERREIRA \& MAIA-BARBOSA, 2013; ELLSWORTH et al. 2015).

A research priority in restoration ecology is to find alternatives to control problem species, such as $M$. maximus, in restoration sites, as they can increase restoration failure by slowing succession and increasing fire frequency and intensity (MANTOANI et al. 2012; ELLSWORTH et al. 2015; MANTOANI \& TOREZAN 2016). Indeed, in many reforestation sites, the understory is dominated by invasive grasses even after several years and under increased canopy cover (MANTOANI et al. 2012; QUESTAD et al. 2012). Factors other than age and canopy cover, and interactions among factors, need to be investigated to explain grass abundance and to guide site management.

Therefore, the goal of this study was to investigate the effects of planting age, canopy openness, reforestation species richness and abundance, and soil fertility on the abundance of ruderal species, M. maximus and other grasses. Given that some degree of shade tolerance is already reported for this species, we asked the following question: Is there a threshold in reforestation canopy openness that leads to grass displacement?

The answers to these questions should be useful in understanding the ecology of early-successional ecosystems and for designing or adapting restoration practices such as tree spacing, fertilizing, and weeding.

\section{MATERIAL AND METHODS}

At the Capivara Reservoir of the Parapanema River in southern Brazil, 17 reforestation sites with native species were sampled. The original vegetation was semideciduous Atlantic Forest, which was cleared in the 1940 's; the land was used for coffee plantations and cattle ranching until the 1970's.

Before restoration, soybean was cultivated on all sites. Since 2001, a hydroelectric power company has reforested the sites using an average 45 native tree species with $2 \times 3-\mathrm{m}$ spacing. Neither $\mathrm{pH}$ correction nor nutrient enrichment was used in the tree seedling plantings, but the previous soybean cultivation included heavy dolomite liming and phosphorus fertilization. The area around each seedling was weeded by hand, and rows between seedlings were mechanically weeded for 24 months from planting. After restoration began, the sites were not burned or cut.

The reforestation age varied from 40 to 110 months. In each site, 10 plots $\left(10 \mathrm{~m}^{2}\right)$ were established to sample planted trees and locate measuring points for canopy openness. Canopy openness was estimated by hemispherical photographs taken one meter above the soil and analyzed using Gap Light Analyzer v. 2.0.

To record the dry biomass of ruderal species, Megathyrsus maximus alone and other grasses together, one subplot $\left(1 \mathrm{~m}^{2}\right)$ was established in each corner of each plot. In these subplots, all aerial portions of grass were cut and dried in paper bags at $85^{\circ} \mathrm{C}$. Independent grass clumps above the ground layer of vegetation were counted as separated individuals. All data were collected in the rainy season.

One pooled surface soil sample (0-20 cm deep) was collected per plot, taken from each of the subplots. Samples were analyzed by the Instituto Agronômico do Paraná laboratory in Londrina, Brazil for $\mathrm{pH}$ and nutrient content (phosphorus, potassium, calcium, and magnesium) according to the methods of Pavan et al. (1992).

Ruderal species, Megathyrsus maximus and other grasses density (in clumps per $\mathrm{m}^{2}$ ) and dry biomass $\left(\mathrm{g} / \mathrm{m}^{2}\right)$ were treated as dependent on planting age, canopy openness, and soil fertility. Data were analyzed using sites as replications, and the reported values for sites are averages of 10 plots. Data normality was verified using the Kolmogorov-Smirnov test and linear or exponential regression was performed. Canopy openness was transformed with arcsine of the square root of the proportion, and other variables were log transformed. For all tests, $\alpha=0.05$ was considered.

FLORESTA, Curitiba, PR, v. 50, n. 4, p. 1931 - 1938, out/dez 2020

Dias, J. et.al.

ISSN eletrônico 1982-4688

DOI: 10.5380/rf.v50 i4. 67192 


\section{RESULTS}

Guinea grass dry biomass ranged between 0 and $182 \mathrm{~g} / \mathrm{m}^{2}$ and density ranged from 0 to 2 occurrences per square meter, but abundance did not decrease with time (Fig. 1).
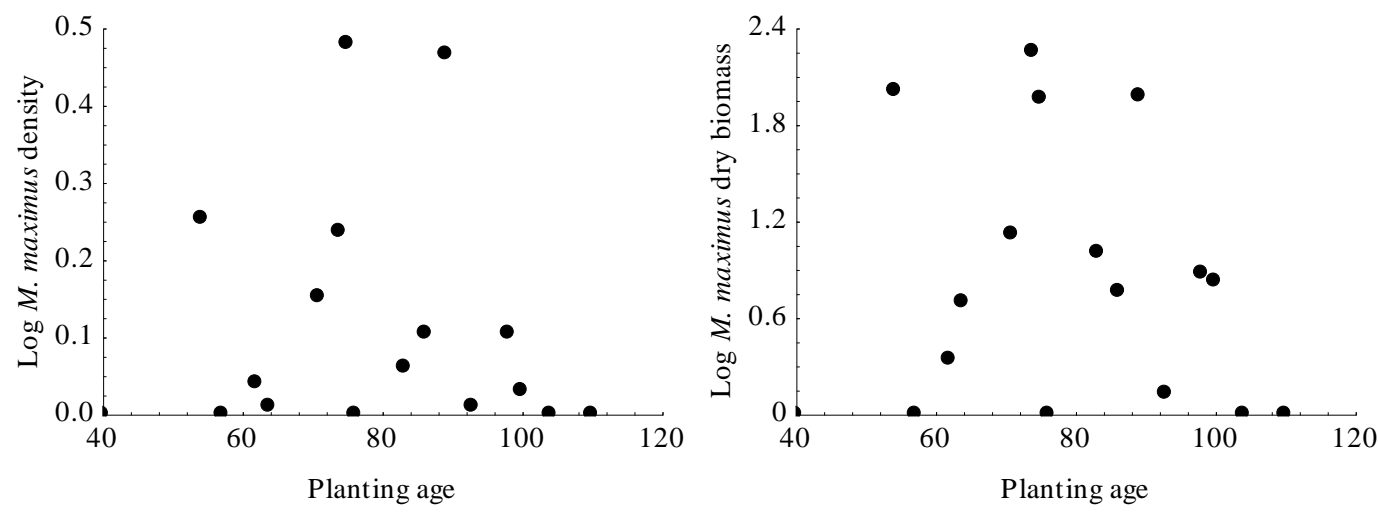

Figure 1. Planting age and A. Log M. maximus density and Log M. maximus dry biomass in restoration sites in Semideciduous Atlantic Forest in Brazil.

Figura 1. Idade do Plantio e densidade de M. maximus (Log) e biomassa seca de M. maximus (Log) em áreas de restauração de Floresta Estacional Semidecidual no Brasil.

Planted tree density ranged from 94 to 293 per $1000 \mathrm{~m}^{2}$ but did not explain grass abundance or dry biomass. Canopy openness ranged from $21 \%$ to $43 \%$ and while there was a negative relationship between planting age and canopy openness (Fig. 2), M. maximum abundance did not depend on the canopy openness (Fig. $3)$. Nutrient concentrations in soil samples indicated an overall high fertility in soils of all sites. Nonetheless, under high concentrations of most nutrients, neither M. maximus abundance nor dry biomass correlated with nutrient availability, with exception for magnesium, which explained grass density (Fig. 4). Ruderal species biomass ranged between 0 and $36 \mathrm{~g} / \mathrm{m}^{2}$ and density ranged from 0 to 13 occurrences per square meter. Ruderal species abundance, but not biomass, showed a positive relationship with canopy openness and a negative correlation with planting age (Fig. 5).

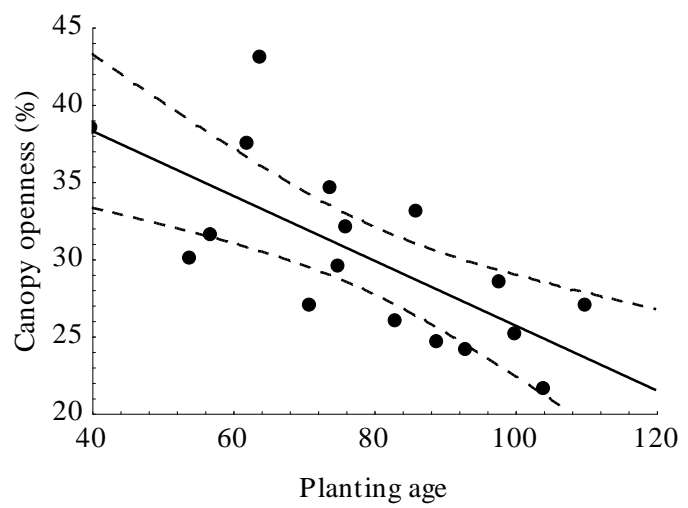

Figure 2. Canopy openness and planting age $\left(n=17 ; r^{2}=0.50 ; \beta=-0.70 ; p=0.001\right)$ in restoration sites on semideciduous Atlantic Forest in Brazil. The continuous line is the regression line and dotted lines indicate the $95 \%$ confidence interval.

Figura 2. Abertura de dossel e idade do plantio $\left(n=17 ; r^{2}=0.50 ; \beta=-0.70 ; p=0.001\right)$ em sítios de restauração da Floresta Estacional Semidecidual no sul do Brasil. A linha contínua é a regressão e as linhas pontilhadas indicam o intervalo de confiança de $95 \%$. 

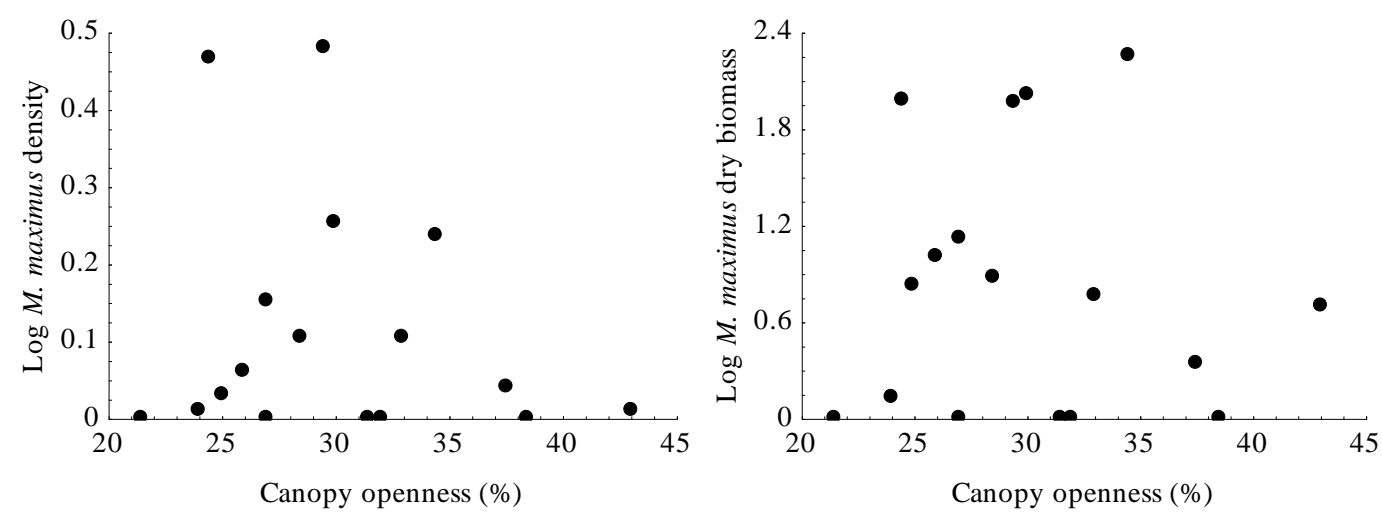

Figure 3. Canopy openness and: Log M. maximus density; Log M. maximus dry biomass in restoration sites in semideciduous Atlantic Forest in Brazil.

Figura 3. Abertura de dossel e: Densidade de M. maximus (Log); biomassa de M. maximus (Log), em sítios de restauração da Floresta Estacional Semidecidual no sul do Brasil.

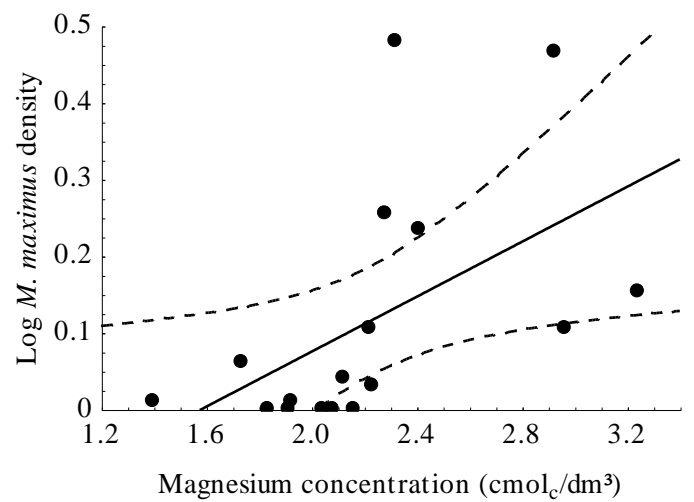

Figure 4. Magnesium concentration and Log Megathyrsus maximus density $\left(n=17 ; r^{2}=0.52 ; \beta=0.68 ; p=0.02\right)$ in restoration sites on semideciduous Atlantic Forest in Brazil. The continuous line is the regression line and dotted lines indicate the $95 \%$ confidence interval.

Figura 4. Concentração de Magnésio e densidade de Megathyrsus maximus $(\log )\left(\mathrm{n}=17 ; \mathrm{r}^{2}=0.52 ; \beta=0.68 ; \mathrm{p}\right.$ $=0.02$ ) em sítios de restauração da Floresta Estacional Semidecidual no sul do Brasil. A linha contínua é a regressão e as linhas pontilhadas indicam o intervalo de confiança de $95 \%$.
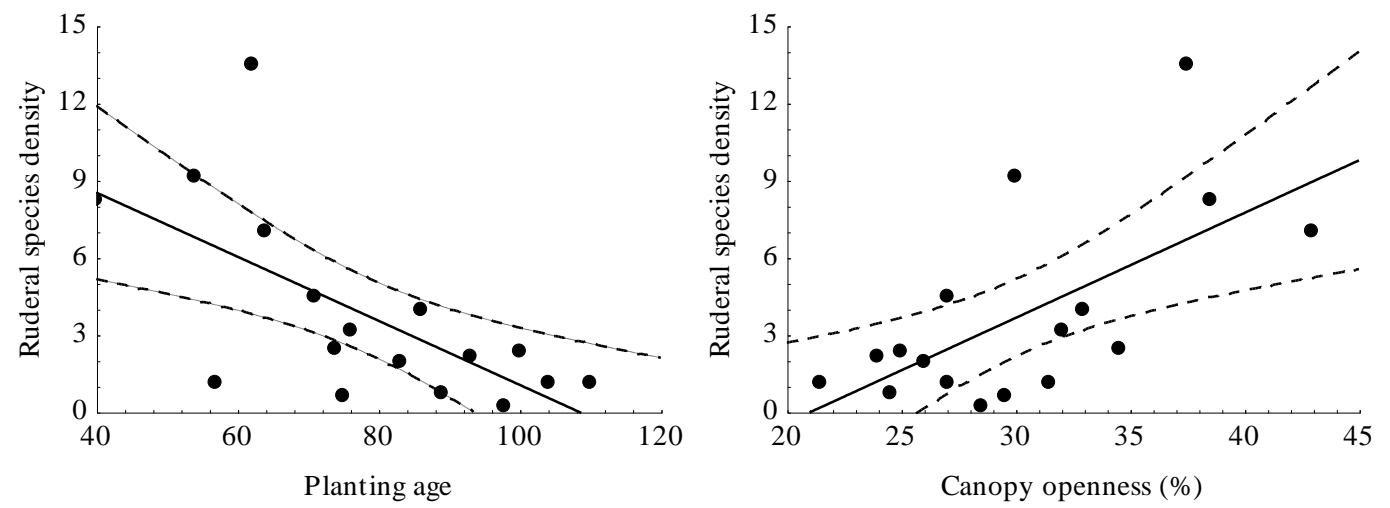

Figure 5. Planting age $\left(n=17 ; r^{2}=0.43 ; \beta=-0.65 ; p=0.004\right)$ and Canopy openness $\left(n=17 ; r^{2}=0.41 ; \beta=0.64\right.$; $\mathrm{p}=0.005) \mathrm{x}$ ruderal species density in restoration sites in semideciduous Atlantic Forest in Brazil. The continuous line is the regression line and dotted lines indicate the $95 \%$ confidence interval.

Figura 5. Idade do plantio $\left(n=17 ; r^{2}=0.43 ; \beta=-0.65 ; p=0.004\right)$ e abertura de dossel $\left(n=17 ; r^{2}=0.41 ; \beta=\right.$ $0.64 ; \mathrm{p}=0.005) \mathrm{x}$ densidade de espécies ruderais em sítios de restauração da Floresta Estacional Semidecidual no sul do Brasil. A linha contínua é a regressão e as linhas pontilhadas indicam o intervalo de confiança de $95 \%$. 
The biomass of other grasses, such as Cenchrus echinatus L., Chloris elata Desv. and Digitaria insularis (L.), ranged between 1 and $142 \mathrm{~g} / \mathrm{m}^{2}$ and the density ranged from 1 to 5 occurrences per square meter. Both dry biomass and density decreased with planting age (Fig. 6), and the density also correlated with canopy openness (Fig. 7). Among all soil fertility variables, only phosphorus concentration explained the density and dry biomass of other grasses (Fig. 8).
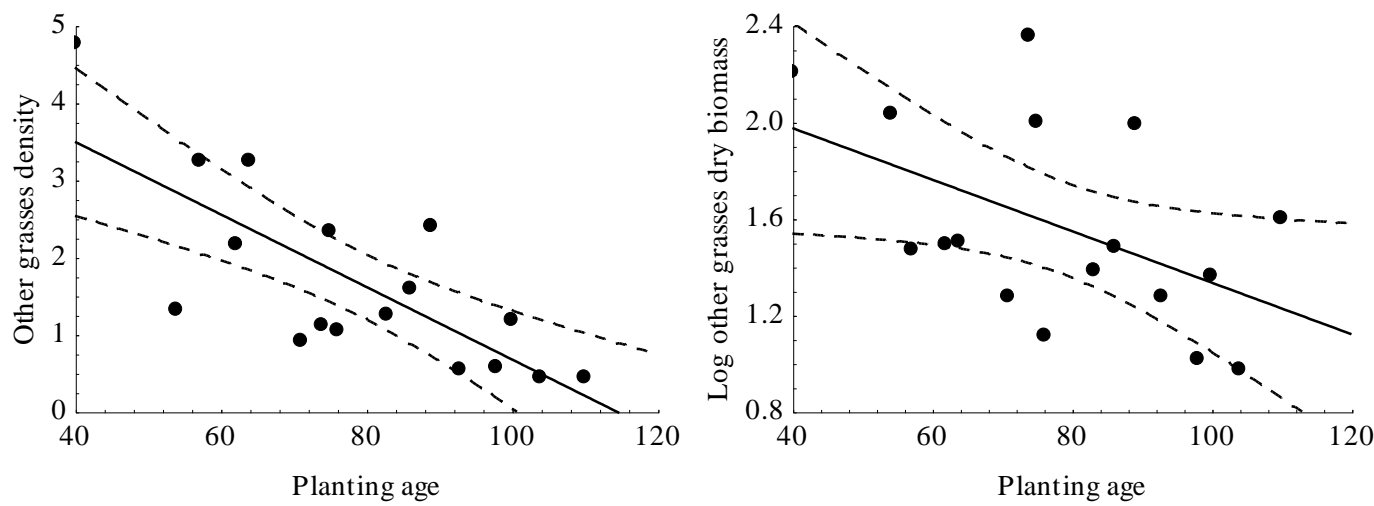

Figure 6. Planting age and density of other grasses, except $M$. maximus $\left(\mathrm{n}=17 ; \mathrm{r}^{2}=0.57 ; \mathrm{r}=-0.75 ; 0.66 ; \mathrm{p}=\right.$ 0,0004); Planting age and other grasses dry biomass, except $M$. maximus $\left(\mathrm{n}=17 ; \mathrm{r}^{2}=0.41 ; \beta=0.64 ; \mathrm{p}\right.$ $=0.005$ ) in restoration sites in semideciduous Atlantic Forest in Brazil. The continuous line is the regression line and dotted lines indicate the $95 \%$ confidence interval.

Figura 6. Idade do plantio e densidade de outras gramíneas, exceto $M$. maximus $\left(\mathrm{n}=17 ; \mathrm{r}^{2}=0.57 ; \mathrm{r}=-0.75 ; 0.66 ; \mathrm{p}\right.$ $=0,0004)$; Idade do plantio e biomassa seca de outras gramíneas, exceto $M$. maximus $\left(\mathrm{n}=17 ; \mathrm{r}^{2}=0.41\right.$; $\beta=0.64 ; p=0.005$ ) em sítios de restauração da Floresta Estacional Semidecidual no sul do Brasil. A linha contínua é a regressão e as linhas pontilhadas indicam o intervalo de confiança de $95 \%$.

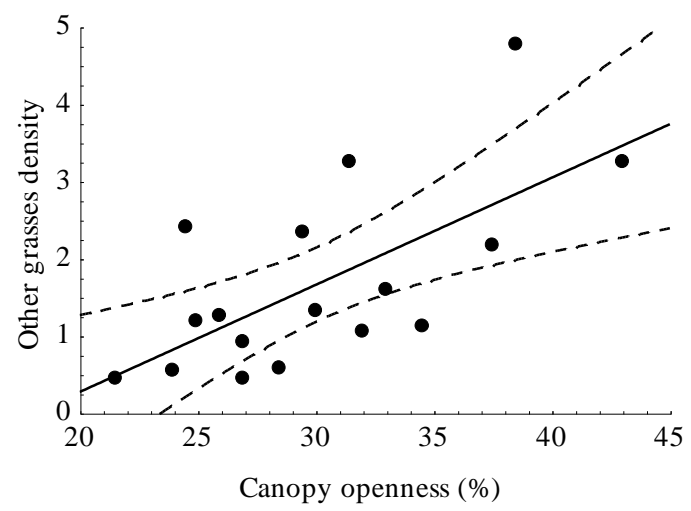

Figure 7. Canopy openness and other grasses density, except $M$. maximus $\left(\mathrm{n}=17 ; \mathrm{r}^{2}=0.44 ; \beta=0.66 ; \mathrm{p}=0.003\right)$ in restoration sites in semideciduous Atlantic Forest in Brazil. The continuous line is the regression line and dotted lines indicate the $95 \%$ confidence interval.

Figura 7. Abertura de dossel e densidade de outras gramíneas, except M. maximus Canopy openness and other grasses density $\left(\mathrm{n}=17 ; \mathrm{r}^{2}=0.44 ; \beta=0.66 ; \mathrm{p}=0.003\right)$ em sítios de restauração da Floresta Estacional Semidecidual no sul do Brasil. A linha contínua é a regressão e as linhas pontilhadas indicam o intervalo de confiança de $95 \%$. 

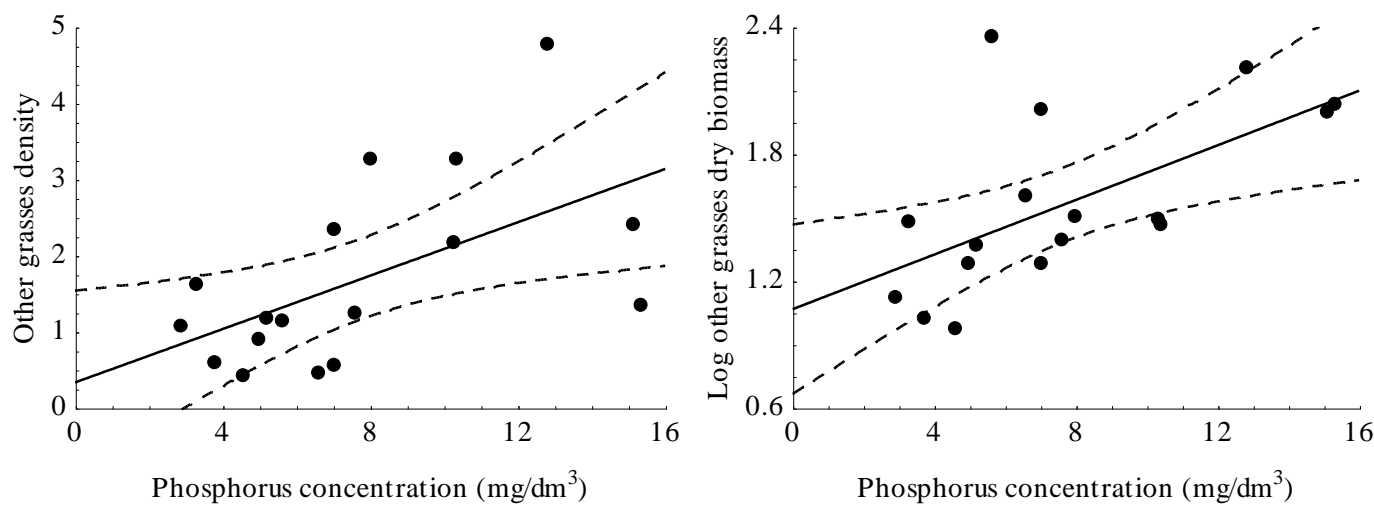

Figure 8. Phosphorus concentration and other grasses density, except M. maximus $\left(n=17 ; r^{2}=0.31 ; \beta=0.56 ; p\right.$ $=0.01)$; Phosphorus concentration and other grasses dry biomass $\left(n=17 ; r^{2}=0.36 ; \beta=0.60 ; p=0.01\right)$ in restoration sites in semideciduous Atlantic Forest in Brazil. The continuous line is the regression line and dotted lines indicate the $95 \%$ confidence interval.

Figura 8. Concentração de Fósforo e densidade de outras gramíneas, exceto M. maximus $\left(\mathrm{n}=17 ; \mathrm{r}^{2}=0.31 ; \beta=\right.$ $0.56 ; \mathrm{p}=0.01$ ); Concentração de Fósforo e biomassa seca de outras gramíneas, exceto M. maximus biomass $\left(n=17 ; r^{2}=0.36 ; \beta=0.60 ; p=0.01\right)$ em sítios de restauração da Floresta Estacional Semidecidual no sul do Brasil. A linha contínua é a regressão e as linhas pontilhadas indicam o intervalo de confiança de $95 \%$.

Planted tree density ranged from 94 to 293 per $1000 \mathrm{~m}^{2}$, but did explain neither abundance nor biomass of ruderal species, Guinea grass or other grasses.

\section{DISCUSSION}

While it has been suggested that higher tree density can reduce grass abundance, this was not valid for M. maximus at the studied reforestation sites. There was a negative relationship between planting age and canopy openness, which led to a decrease in abundance of ruderal species, including grasses but not $M$. maximus.

Thus, despite the fact that planted trees likely impose competition for water and light on understory plants, M. maximus remained in the understory, suggesting a higher tolerance to competition than other ruderal species. Indeed, several reports on M. maximus as a forage plant pointed to a high tolerance to shading (DIAS et al. 2016). Both Castro et al. (2001) described high shade tolerance in this species, and Ferreira et al. (2010) reported higher grass dry biomass under moderate shade. Thus, the lack of correlation between grass dry biomass and canopy openness in this study might be related to some degree of shade tolerance by M. maximus. Souza and Batista (2004) also studied semideciduous Atlantic Forest restoration sites and found that increases in canopy cover led to a reduction in M. maximus cover. However, their data did not include grass biomass.

Nutrient concentrations in the soil samples were high, indicating an overall high fertility in soils of all sites (Table 2). Restoration sites showed higher concentrations of nutrients than remnant Atlantic Forest fragments in the same region, which is probably attributable to previous agricultural use. High fertility can benefit all fast-growing plants, including M. maximus. Nonetheless, with high concentrations of most nutrients, neither M. maximus abundance nor dry biomass correlated with nutrient availability, with the exception of magnesium concentration, which explained grass density.

The response of M. maximus to soil nutrient content can be inferred from forage science research, although data are scarce regarding its requirements in degraded and early successional sites. According to Sousa et al. (2010), the productivity of Brazilian pastures is low owing to low soil fertility, but the production of grasses from the genera Panicum and Brachiaria (including species now treated as Megathyrsus and Urochloa). can be high if soil corrections are made; M. maximum is adapted to soils with high fertility (COSTA et al. 2004).

Indeed, Costa et al. (2004) reported that a phosphorus concentration greater than $6.1 \mathrm{mg} / \mathrm{dm}^{3}$ is considered "medium to high" in the context of M. maximus pastures, and 10 out of 17 sites studied here had phosphorus concentrations above that level, which can explain why grass abundance and phosphorus content in the soil were not correlated. Castro et al. (2001) suggested that tropical grasses under shading show higher nutrient concentrations in the leaves and stems as a result of metabolic changes. Magnesium is a constituent of chlorophyll and is also required for many enzymes that are involved in phosphate transfer and nutrient absorption. Eriksen \& Whitney (1981) reported an increase in magnesium concentration in M. maximum leaves 
and stems when cultivated in $75 \%$ shade. Thus, an increase in soil magnesium concentration will likely result in a higher shade tolerance for M. maximus.

\section{CONCLUSIONS}

- After 10 years of restoration with native species in Atlantic Forest sites with high soil fertility, ruderal species and most grasses are being displaced, but Megathyrsus maximus are still growing in the forest understory.

- Reforestation age, canopy cover, and planted tree abundance did not explain variations in M. maximus abundance, nor did most nutrient concentrations, which were high in all soil samples.

- The positive correlation between magnesium concentration and grass abundance points to an interesting question, of whether high soil magnesium content is related to higher chlorophyll content in the grass leaves and thus to an increased shade tolerance by $M$. maximus.

\section{ACKNOWLEDGMENTS}

The authors thank CNPq (Conselho Nacional de Desenvolvimento Científico e Tecnológico) for research grants 305854/2012-7 and 503836/2010-9 to JMDT), and JD thanks CAPES (Coordenação de Aperfeiçoamento de Pessoal de Nível Superior) for a graduate research grant. The authors are also grateful to Odair C. Pavão and the LABRE (Laboratório de Biodiversidade e Restauração de Ecossistemas) team for help in field.

\section{REFERENCES}

AMMONDT SA.; LITTON CM. Competition between native Hawaiian plants and the invasive grass Megathyrsus maximus: implications of functional diversity for ecological restoration. Restoration Ecology, Washington, v. 20, p. 638-646, 2012.

AMMONDT SA.; LITTON CM.; ELLSWORTH LM.; LEARY JK. Restoration of native plant communities in a Hawaiian dry lowland ecosystem dominated by the invasive grass Megathyrsus maximus. Applied Vegetation Science, Washington, v. 16, p. 29-39, 2013.

CASTRO CRT.; GARCIA R.; CARVALHO MM.; FREITAS VP. Efeitos do sombreamento na composição mineral de gramíneas forrageiras tropicais. Revista Brasileira de Zootecnia, Viçosa, v.30, p. 1959-1968, 2001.

COSTA NL.; RODRIGUES ANA.; TOWNSEND CR.; MAGALHÃES JÁ.; OLIVEIRA JRC. Calagem e adubação para pastagens de Panicum maximum cv. Tobiatã em Rondônia. Recomendações técnicas 87. Ministério da Agricultura, Pecuária e Abastecimento, Porto Velho, Rondônia, 2004.

DIAS J.; MANTOANI MC.; BAPTISTA R.; FONTE MAMA.; HOLDEFER D.; TOREZAN JMD. Invasive alien plants in Brazil: a nonrestrictive revision of academic works. Natureza \& Conservação, Rio de Janeiro, v. 11 , p. 31-35, 2013.

DIAS, J.; SURIAN, T.; MANTOANI, MC.; PEREIRA, LCSM.; TOREZAN, JMD. Crescimento de Megathyrsus maximus (Capim-Colonião) e duas espécies nativas arbóreas em diferentes condições ambientais. Floresta, Curitiba, v.46, n.3, p. 325-333. 2016.

ELLSWORTH LM.; LITTON CM.; LEARY JJK. Restoration impacts on fuels and fire potential in a dryland tropical ecosystem dominated by the invasive grass Megathyrsus maximus. Restoration Ecology, Washington, v. 23, p. 955-963, 2015.

ERIKSEN FI.; WHITEY AS. Effects of light intensity on growth of some tropical forage species: interaction of light intensity and nitrogen fertilization on six forage grasses. Agronomy Journal, Madison, v.73, p. 427-43, 1981.

FERREIRA DJ.; ZANINE AM.; SOUTO SM.; DIAS PF. Capim tanzânia (Panicum maximum) sob sombreamento e manejo de corte. Archivos de Zootecnia, Córdoba, v.59, p.81-91, 2010.

FERREIRA, MTS; MAIA-BARBOSA, PM. O fogo como facilitador da invasão biológica por Megathyrsus maximus (POACEAE: PANICOIDEAE) na Terra Indígena Maxacali (MG): Proposta para um manejo agroecológico integrado e adaptativo. Biodiversidade Brasileira, Brasília, v.3, n.2, p. 159-174, 2013.

FLORESTA, Curitiba, PR, v. 50, n. 4, p. 1931 - 1938, out/dez 2020.

Dias, J. et.al.

ISSN eletrônico 1982-4688

DOI: $10.5380 /$ rf.v50 i4. 67192 
MANTOANI MC.; ANDRADE GR.; CAVALHEIRO AL.; TOREZAN JMD. Efeitos da invasão por Panicum maximum Jacq. e do seu controle manual sobre a regeneração de plantas lenhosas no sub-bosque de um reflorestamento. Semina: Ciências Biológicas e da Saúde, Londrina, 33:97-110, 2012.

MANTOANI MC.; TOREZAN JMD. Regeneration response of Brazilian Atlantic Forest woody species to four years of Megathyrsus maximus removal. Forest Ecology and Management, Amsterdam, v. 359, p. 141-146, 2016.

PAVAN MA.; BLOCH MF.; ZEMPULSKI HD.; MIYAZAWA M.; ZOCOLER DC. Manual de análise química do solo e controle de qualidade. Instituto Agronômico do Paraná, Londrina, 1992. 40p.

QUESTAD EJ.; THAXTON JM.; CORDELL S. Patterns and consequences of re-invasion into a Hawaiian dry forest restoration. Biological Invasions, Switzerland, v. 14, p. 2573-2586, 2012.

SAMPAIO, AB.; SCHMIDT, IB. Espécies Exóticas Invasoras em Unidades de Conservação Federais do Brasil. Biodiversidade Brasileira, Brasília,v. 3, n.2, p. 32-49, 2013.

SOUSA RS.; PIRES AJV.; CARVALHO GGP.; SILVA FF.; MAGALHÃES AF.; VELOSO CM. Composição química de capim-tanzânia adubado com nitrogênio e fósforo. Revista Brasileira de Zootecnia, Viçosa, v. 39, p. 1200-1205, 2010.

SOUZA FM.; BATISTA JLF. Restoration of seasonal semideciduous forests in Brazil: influence of age and restoration design on forest structure. Forest Ecology and Management, Amsterdam, v. 19, p.185-200, 2004. 